\title{
An Assessment of the Training and Developmental Needs of Employees in Nigerian Local Government
}

\section{Osabiya Babatunde Joseph*}

B.Sc Degree Programme in Public Administration, School of Management Sciences (SMS) National Open University of Nigeria (NOUN), Victoria-Island, Lagos, Nigeria

\begin{abstract}
The importance of training and development is more obvious given the growing complexity of the work environment, the rapid change in organizations and advancement in technology, among other things. The ultimate aim of any training program is to add value and once a training program cannot add value, it should be reworked or altogether cancelled. Without training, it will be very difficult to acquire skills and without skills organizations will not achieve its objectives through people.
\end{abstract}

Keywords: Understanding training and development; Types of training and development; Relevance of training and reasons why training fail

\section{Introduction}

Training can be argued by all and sundry as an act of equipping human beings with the adequate and necessary knowledge or understanding to enable him/her perform in line with the required standards and expectations to meet up with the objectivity of his manager or organization as a whole [1]. Thus, every organization should involve in training for its employees to enable them perform their job efficiently and effectively for increased productivity.

Staff or employee occupies an indispensable position in any establishment, be it industry, commercial or educational institution. This means that without employees, organization cannot function effectively. In essence, human effort is greatly desirable and crucial in achieving the goals and objectives of the organization. Effective management is used to mean the training of personnel to improve their application of knowledge, skill, behavior or problem solving techniques which they acquire through previous education training and development experience. Training and development is a function and responsibility of the organization concerned [2]. This activity aimed at bettering the performance of individual and group settings.

Training new employees sets the tone for the employee's impression of an organization's culture. So in a sense it's a microcosm of the organization itself. Training new employee represents a golden opportunity to get things off to a good start. It sets momentum for the newly employed. This momentum can be positive for a good experience; however, an unpleasant experience can create negative momentum. This is why an outstanding training experience for newly employed and already employed is vital for both the staff and the organization. A personnel management theorist Ubeku A [3] state that "money spent on training and development of staff is money well invested. Staff, who has not received adequate training before being assigned responsibility, lacks necessary confidence with which to carry-out the job". In as much as people are regarded as a set of the major resources of work performance to a manager, therefore the successful performance of the job depends on the training given to them. To be able to get the best from workers or staff, constant and continuous training exercise should be introduced to them. Training of employee is not for potential reflection of the staff only but for the organization which includes local government council's image as well. If an employee is not given the opportunity of in-service training to better his/her educational position and develop him/her, the tendency to lack the know-how or confidence of assuming higher responsibility abounds.
Training of old and new employee are of paramount importance to boost their morals for better performance of their duty, enhancing improved productivity in realization of the management objectives. Adebayo A [4] emphasized this point, thus:

"The fact which is obvious for anyone is that the Chief Executive be he functioning as permanent Secretary, General Manager, Executive Secretary to body of organization cannot by himself alone accomplish the requirements of his office without the efficient support and assist on of other functionaries lower the ladder"

A proportionate period of the first one-month of a new employee in the organization or local government council should be used for induction purposes. This is a form of training because during the period, the employee acquits his or herself with the local government area or organizational structure and setup in form of socialization.

The overall emphasis of this research work is to implore the local government council bosses or authorities/heads of various departments to encourage employees by giving them adequate training facilities at intervals as an incentive and most recognized motivator [5]. The need for human resources training and development cannot be overemphasized, because it is an investment in human ability that leads to human capability. It should therefore occupy a unique space in the undertaking of the local government council as an indispensible part of the local government council authorities' function. Training is relevant to administration, as it is essential to overall employees. In totality, every category of staff in the Local Government Council deserves to be trained and should be desirous of being trained for his/her personal improvement and local government area achievement for desired objectives. The most conspicuous and effective lubricant to employee's efficient and productive performance of his/her job is training.

There is need for employees training and development in any organization including Local Government Councils to ensure better

*Corresponding author: Osabiya Babatunde Joseph, Assistant Lecturer Programme Coordinator: B.Sc Degree Programme in Public Administration, School of Management Sciences (SMS) National Open University of Nigeria, VictoriaIsland, Lagos, Nigeria, Tel: 2348033869291; E-mail: osabiyababatunde@yahoo.com.

Received April 04, 2015; Accepted April 30, 2015; Published May 08, 2015

Citation: Joseph OB (2015) An Assessment of the Training and Developmental Needs of Employees in Nigerian Local Government. Review Pub Administration Manag 3: 152. doi:10.4172/2315-7844.1000152

Copyright: @ 2015 Joseph OB. This is an open-access article distributed under the terms of the Creative Commons Attribution License, which permits unrestricted use, distribution, and reproduction in any medium, provided the original author and source are credited. 
performance [6]. The importance and significance of training and development to organizational development has no doubt been recognized in some Local Government Council or in the Nigerian Public Services. Some of the problems of Local Government Councils include the following;

(a) Non-Adherence to the recommendation of the 1988 and 1998 Civil Service Reform:

Local government councils of the federation had failed to adhere to the civil service recommendation which stipulates that ten percent (10\%) of the total annual personnel emolument be set aside for staff training and development. The federal government and state government have equally failed in this regard in the implementation of this reform (absence of systematic training).

(b) Poor awareness and exposure of Local Government Council Authorities to relevance of training and development of employee: This is a major problem, being the pilot of all affairs and owing to the fact that $80 \%$ of the workforce of the local government council is junior staff (level 1-6) and as such the council authority considers it irrelevant to spend money on training lower cadre employees.

(c) Poor funding and embezzlement: this is reflected in the difference between budgetary provisions and actual funds released for various years both at federal, state and local government levels

(d) High cost of training has been occasioned by lack of transparency and honest: The cost of bribes is often built into the training costs when signing contracts with training consultants and this may affect quality of training.

(e) Poor utilization of trained employees: Many employees sent for training is not allowed to utilize their skills and knowledge because of bureaucratic rigidity and unwillingness to change [7]

(f) Lack of proper consideration for training needs: Many times, employees are sent for training without proper consideration for the relevance to present job or future posting

(g) Employees misconception on Training and development: Some employees considers training as unnecessary and waste of time, resources and energy as they believe experience is a better teacher than any training programme or exercise. Curricula and methods remain insufficiently attuned to job content due to several factors such as funding, size of the trainees etc.

(h) Lack of incentives for trained personnel: Being that lower cadre employees (level 1-6) constitute $80 \%$ of the workforce of the local government council, some employee sees training and development as stressful and unnecessary while some concedes that even if they undergo the training, the local government council authority may not consider them for proper placement which commensurate with their newly acquired skill or certificate.

(i) The use of quack consultants by local government council authority has grossly affected the quality of training: In many instances, the council authority prefers to contract training programs to political or party associates, loyalists or family affiliates rather than competent and experienced specialist in the consulting firms.

(j) Inadequate Training Facilities: Modern facilities to train and enhance development are not available neither assessed even when it is scarcely available.

\section{Literature Review}

Training or employee training also known as job training, occupational training or vocational instruction for employed persons by some personnel management theorist or scholars can be traced(back) to during and after World war II, when in-service training by employers became a common practice. The rapid change-over in industry from peace to war led to training schemes for semi-skilled workers, for workers transferred to new jobs, and for women newly brought into industry. Therefore, the rapid contemporary advance of technological change made training a necessity in almost all works of life. At the operating level in industry and public utilities, new techniques, new methods, new tools, new synthetic, new sources of power, and increased uses of automation have brought extensive changes in the past decades and the rate of change tends to increase as time goes on. Comparable changes are taking place in the office with extended use of computers and data processor, which provide for the storing and recall of information. All of these brought a new approach to training. Great emphasis is now placed on a good start through initial job training, supplemented by orientation sessions or by attractively produced printed materials describing the nature and objectives of the employment.

Traditionally, training and development dates back to the time of our fore fathers, who taught their children through verbal means and demonstrations (hand-work) on how to do things. An example of such verbal and demonstrative means of training used by our ancestral fathers includes occupation like blacksmithing, hunting, farming; wrestling etc and the ones who mastered these skills have always come out successfully. Therefore, the process of transferring knowledge through verbal and demonstrative means is realized today by scholars as training and development.

Virtually, all modern organization place emphasis on skilled manpower for attainment of their organizational goals and aspirations. Thus, for any organization aspiring to meet the objectives for which it is established, there must be deliberate policy to train and develop its employees.

Recruitment of qualified personnel is not synonymous with training. Every employee in any organization needs some sort of orientation and continuous development. The need for this retraining is to enable the employee meet the challenging modern industrial complexities and take on higher responsibilities and attainment of selffulfillment.

The new Civil Service Reform of 1998 clearly emphasizes the importance of training and development. The reform stressed that opportunity should be given to employees to make a career in whatever discipline they can. The reforms also emphasize that training is a right of all civil servants if they must grow.

Employees are motivated through training, which ultimately determine their utilization, productivity, commitment and growth Many employees have been frustrated because their needs for training were not identified and provided for as an indispensible function of management.

In this regard, several authors have postulated series of works on the phenomenon of training and development.

Robbins S.P [8] "training is concerned with the present development, and the future organization which cannot afford to stand still. They must be ready for change, and so must the people who comprise them". 
Based on the foregoing, training and development have been directed to individuals holding managerial positions in recent years. But today, establishments, departments have now seen the need to make all caliber of employees ranging from unskilled, semi-skilled and the skilled or professionals benefit from the training programmes of such establishment as proficiency at all level of an organization goes a long way to increasing the total output of such organization.

According to Ubeku AK [3] "Training schemes for all categories of employees are vital in any organization that wants to stay in a competitive world. Machinery is becoming more and more complex and even where automation takes over; different types of skills are required. Therefore, there must be constant training and retraining of employees. With regard to managers, there are not enough managerial skills at the moment and most organizations are engaged in management training within Nigeria and abroad." Bearing in mind the complexity, and the high rate of technological and philosophical world we now live in, the need for training and development therefore becomes greatly pertinent. The days when jobs were learnt with little or no regard to technological changes are gone.

The management of employees these days' calls for higher degree of training and development of the mentality of the one charged with the administration of staff. Hence, in the local government, there are various department charged with different responsibilities. Training and development in this regard, helps in modifying the behavior of the trainee or trained officer in order to afford him the opportunity to function properly in that position.

Appleby R.C [9] "training is required to make persons behave differently or more efficiently". There is no over-stressing the fact that the skill of persons that have undergone training for specific period must improve since the objective of training and development is to enhance and increase the level of performance of the individual.

According to Jucious "training is the process of acquiring specific skills to perform a job better". It helps people to become qualified and proficient in doing some jobs.

Usually an organization facilitates the employees learning through training so that their modified behavior contributes to the attainment of the organization's goal and objectives.

Van Dersal defined training "as the process of teaching, informing, or educating people so that they may become as well as qualified as possible to do their job, ${ }^{(2)}$ they become qualified to perform in positions of greater difficulty and responsibility".

Arnoff [10] observes that training and development foster the initiative and creativity of employees and help to prevent manpower obsolescence, which may be due to age, attitude or inability of a person to adapt him or herself to technological changes.

Obisi [11] "training is a process through which the skills, talent and knowledge of an employee is enhanced and increased". He argues that training should take place only when the need and objective for such training have been identified.

Scott, Clothier and Spriegal agree that training is the cornerstone of sound management, for it make the employees more effective and productive. They argued that training is actively and intimately connected with all the personnel and managerial activities. It would be difficult for a new employee to grow on the job and become a manager without adequate training and development.
Craig [12] in his work on training has this to say "the place of training and learning is the sky-rocketing development of knowledge and civilization has become dramatically evident".

However, with the advent of industrial revolution in the $18^{\text {th }}$ century, the history of training and development that accompanied the industrial era, then fell on the increase. For organization to keep on the pace of effective and efficient management, training of personnel becomes pertinent.

In this regard, Knootz and Donnel [13] postulated that: "The lessons learned from these experiences were so valuable that managers possessed special knowledge and skills which could be explained took firm hold." With the acquiring of adequate knowledge and skills, the technicalities accompanying management in an organization become simple and well administered to ensure rapid productivity. Without training and development of personnel to meet with the increase in technology, management today would have been a difficult and complex subject to approach.

Training and development therefore becomes a process whereby planning has to be applied to make training and development manifest its true goals and objectives, by carefully, analyzing the present and critically looking into the future jobs in order that training becomes effective.

Knootz and Donnel [13] in their book say: "A good training programme is not static; it considers the training needs of managers in the present job and the next job. It also takes into accounts broad enterprise needs and plan in the distant future". The main objective is to improve current performance and provide a suitably trained staff to meet present and future needs.

Training includes seminars and workshops as well as short courses in higher institutions of learning. "Training is the systematic development of knowledge, skill and pattern required by an individual in order to perform a given task". "Training is process of learning a sequence of programme behavior". "Training is concerned with job performance and the application of knowledge and skill to present job".

In his realization of the significance of training of the public servants, Udoji [14] recommended that: "it should be a usual practice in all ministries to arrange training programme for their personnel of all grades as a way of improving efficiency and quality of the service."

Ubeku [15] speaks of training, thus: "Money spent on the training and development of employees is money well invested. Employees who have not received adequate training before being assigned with responsibilities lack the necessary confidence with which to carryout jobs. Because he believes he can do it, his enthusiasm on the job increases. It is a person in that position who can think and originate ideas as to how be the best to carry out the task of the job. People who are not trained tend to stick to what they were taught the first time then they took over the job. They are frightened of doing the job in different way, because something might go wrong and that risk they cannot take".

Garavan et al. postulated that: "Training and development encompasses three main activities: training, education and development;

Training - this is both focused upon, and evaluated against, the job that an individual currently holds,

Education - this activity focuses upon the jobs that an individual 
may potentially hold in the future, and is evaluated against those jobs,

Development - this activity focuses upon the activities that the organization employing the individual, or that the individual is part of, may partake in the future, and is almost impossible to evaluate".

Conroy [16] defined manpower development "as a purposive effort intended to strengthen the library's capability to fulfill its mission effectively and efficiently by encouraging and providing for the growth of its own human resources". He desired manpower development as a factor that improves the competence of personnel through opportunities for learning on the job. This implies that manpower development can be achieved through training and education of staff.

Biscoe [17] sees staff development as a two way responsibility within the organization and individual. Sodipo [18] investigated the effect of manpower development on productivity with the aim of determining the different factors that play important roles in any organizational setup for effective utilization of manpower resources available to it, its main focus is on different factors that play important role in organizational to ensure effective information management.

McNamara [19] views training as involving an expert working with learners to transfer to them certain areas of knowledge or skills to improve in their current jobs. However, manpower development is not a responsibility of just an individual; rather it is a combination of different factors.

\section{Understanding Training and Development}

According to Obisi [20] the concepts of training and development are used interchangeably. However, it can be differentiated from the other. Training is for specific job purpose while development goes beyond, specifies development cover not only those which bring about growth of personality.

Steinmetz and Lawrence notes that training is a short term process, utilizing a systematic and organized procedures by which nonmanagerial personnel learn technical knowledge and skill for definite purpose. Development on the other is long term educational process utilizing procedure by which managerial personnel learn conceptual and theoretical knowledge for general purposes.

Campbell [21] says that training refers only to instruction in technical and mechanical operations while development refers to philosophical and theoretical educational concept. Training is designed for non-managers while development involves managerial personnel. Training courses are typically designed for short term stated purpose, such as the operation of some piece(s) of machinery while development involves a broader education for long-term purpose. Training is for short term while development is for long-term. Training is for specific job related purposes while development is general purpose.

\section{Types of Training and Development}

There are two (2) major types of training, On-the-job training and Off-the-job training as identified by Alo, O. (1999); On-the-job training is normally handled by colleagues, supervisors, managers, mentors to help employee adjust to their work and equip them with appropriate job related skills [22].

Armstrong [23] argues that On-the-job training may consist of teaching or coaching by more experienced people or trainers at the desk or at the bench. It may consist of individual or group assignment and projects and the use of team leaders and managers. Armstrong furthered that on-the-job training is the only way to develop and practice the specific managerial, team leading, technical, selling, manual and administrative skills needed by the organization and its has the advantaged of actuality and immediacy as the individual works, learns and develops expertise at the same time.

Disadvantages of On-the-job training according to Armstrong [23]; are that the effectiveness of the learning is strongly influenced by the quality of the guidance and coaching provided on the job. Many managers and team leaders are unskilled at training and undisciplined to carry it out or to encourage it. Furthermore, relying on fellow employees in "sit by me" training has obvious disadvantages as instruction may be inadequate and the training may perpetuate bad habits. Again, the learner may be distracted by the same environment and find it difficult to acquire basic skills quickly.

According to Ejiogu [24] Off-the-job training would include vestibule training, role playing, case study, discussion and simulation. Armstrong [23] listed group exercises, team building, distance learning, outdoor and workshops as part of Off-the-job training.

He further explains that Off-the-job training may be provided by members of training department, external education and training establishments or training providers- training consultants or guest speakers. He encourages line managers to be closely involved to bring reality into the classroom, to case the transfer of learning, and to make sure that those involved in Off-the-job training are carefully selected, briefed and monitored so as to ensure that they make the right contribution.

\section{Objectives of Training and Development}

Some of the main objectives of training and developing employees include:

a. To povide the knowledge and appreciation of techniques necessary to enable employee function in their jobs.

b. To broaden the employee's horizon of the society in which he or she finds or lives and develops his or herself as a confident person.

c. To prepare suitable employee for more educated study leading to highly skilled work.

d. To afford the employees the opportunity of changing their schedules of duties and be able to perform equally well on them.

\section{Training Benefits}

When advance training was introduced some employees consider it punishment and stressful in meeting and learning something new but nowadays, employees consider training as an opportunity and as a highly regarded organizational benefit [25-29]. Employees appreciate training opportunities for many reasons including:

- They can learn something that will make their job easier or more enjoyable.

- It increases their 'stock value' within the organization. They become more desired.

- It could lead to promotion, pay-rise or a new title.

- They can include it in their resume someday in the future.

- They feel needed and appreciable, relevant to the organization, because their employer is willing to invest time and money into their learning experience. 
- It gives them the chance to do something different other than their daily job.

- They can be around other employees or peers and build camaraderie (familiarity and sociability).

Therefore, it can benefit the employee in number of positive ways. Providing opportunities can also benefit the employer or organization in a number ways which includes:

- Their employees become more efficient at performing their jobs.

- It builds organization morale.

- It increases loyalty and reduces turn-over of highly regarded employees.

- It projects the organization as a preferred workplace to external or aspiring candidates

- It enhances or stimulates employee creativity.

- It keeps the training department fresh and invigorated.

\section{Relevance of Training and Reasons Why Training Fail}

Relevance of training is a very important issue that the organization should look critically at, if they really want to improve the effectiveness of their employees [30-33]. Any training program that is not relevant should not be undertaken. Training should be designed to solve problems and to fill gaps in employee performance. Training should make things happen and bring about needed changes that would enhance organization's effectiveness. It is not proper for an organization to embark on any training program which is not relevant to it and its people [34].

Armstrong [23] agrees that for training program to be relevant, it must satisfy identified and appropriate needs.

According to Kenney and Reid planned training is the deliberate intervention aimed at receiving the learning necessary for improved job performance. Planned training according to Kenney and Reid consists of the following steps:

- Identify and define training needs

- Define the learning required in terms of what skills and knowledge have to be learnt and what attitudes need to be changed

- Define the objectives of the training

- Plan training programs to meet the needs and objectives by using right combination for training techniques and locations.

- Decide who provides the training

- Evaluate training.

- Amend and extend training as necessary.

Organization training practices can fail for many reasons. Burak, Elmar and Smith, Robert [35] give the following reasons:

- The benefits of training are not clear to employees.

- The organization hardly rewards supervisors for carrying out effective training.

- The organization rarely plans and budgets systematically for training.
- Training external to the employing unit sometimes teaches techniques on method contrary to practice of the participants scheduling.

- Trainers provide limited counseling and consulting services to the rest of the organization.

\section{Methodology}

The researcher used secondary data and its information was gathered from various textbooks, journals, periodicals, newspapers and magazines.

\section{Conclusion}

Since the success of any organization depends on the available quality of human resources at its disposal, then training of employees in an organization should be a compulsory programme irrespective of their previous education or technical qualifications before their assumption of duty. "No one is a perfect fit at the time of living". Therefore training programme must be given utmost priority by every employee.

In further recognition of proper efficiency of employee job performance, up-to-date training must be given to employees. Training should be taken as a continuous process. It is therefore necessary to update the skill of manpower from time to time. Systematic, well organized and implemented training programme will afford the organization increase in productivity, heightened morale, reduce redundancy and help employees to stay longer in the organization for the realization of its objectives.

\section{Recommendations}

The benefits accruing from employees training and development cannot be overemphasized.

Outputs and results of this study have necessitated the researcher to recommend the following for efficient management in the Local Government Council or other organizations.

1. Training programmes should be provided to cover all categories of staff that have requisite academic and professional qualification required for their proposed training.

2. On-the-job manpower development programs like in-house training, seminars, conferences, short course, workshops etc should be arranged for those employees who could not be sent on Off-the-job training or those with deficiencies.

3. The newly employed who benefited from manpower training should be promoted as soon as possible so as to give them the opportunity of assuming the level of responsibility that is commensurate with their newly acquired qualification.

4. Certain percentage of local government council subvention or allocation should be set aside for training programmes.

5. The training programme policy of the Council could be improved, more fund should be made available to enable the employees on training paid their entitlements adequately with the view to giving them the required support for the training.

6. For convenient management of manpower and organization, training program should be placed on priority list of the Local Government Council's budgets.

7. The Local Government Council Authorities should recognize 
Citation: Joseph OB (2015) An Assessment of the Training and Developmental Needs of Employees in Nigerian Local Government. Review Pub Administration Manag 3: 152. doi:10.4172/2315-7844.1000152

Page 6 of 6

and appreciate outstanding employee and reward him or her hard-work accordingly.

8. The Local Government Council Authorities should encourage delegation of duties from time to time to ensure regular onthe-training.

9. Local Government Council Authorities has failed in the past in adhering to the Civil service reforms and the Federal and state government should ensure strict compliance to the reforms which encourages manpower training and development.

\section{References}

1. Adamolekun L (1983) Public Administration: Nigeria and Comparative Perspective. Longmans, London.

2. Cole G (1982) Management Theory and Practice. 2nd Edition, D.P. Publications Ltd.

3. Ubeku A K (1975) Personnel Management in Nigeria. Ethiope Publishing Corporation, Benin City.

4. Adebayo A (1981) Principles and Practice of Public Administration in Nigeria John Willey and Sons Ltd.

5. Craig R (1976) Training and Development Handbook. McGraw-Hill Publishing Company Ltd.

6. Fajana S (1997) Human Resources Management. Labofin and Company, Lagos.

7. Appleby R (1969) Modern Business Administration. Pitman Books Ltd, London.

8. Robbins S (1978) Personnel: The management of Human Resources. New Jersey: Prentice-Hall Inc.

9. Appleby R (1969) Modern Business Administration. Pitman Books Ltd.Scott, London.

10. Arnoff J (1971) Achievement Motivations Training and Executive Advancement. Journal of Applied Science 7: 12-24

11. Obisi C (2001) Employee Development, Issues and Dimension. Unical Journa of Public Administration 1: 15-36.

12. Craig RL (1976) Training and Development Handbook. McGraw-Hill Publishing Company Ltd.

13. Knootz H, Donnel CO (1978) Essentials of Management. McGraw-Hill Book Company.

14. Udoji J (1975) The Implications of the Public Service Review Commission's Report for Management Education and Training". A Quarterly Journal of Administration 10: 5-11
15. Ubeku A (1978) Personnel Management in Nigeria. Second edition, Ethiope Publishing Corporation, Benin.

16. Conroy B (2001) Library Staff Development and Continuing Education: Principles and Practice. Harper and Row, New York.

17. Biscoe M (2002) Human Resource Development and Utilization. Spectrum Books, Ibadan.

18. Sodipo A (2005) Manpower Development and its Effect on Productivity McGraw Hill, Auckland.

19. Mcnamara C (1999) Employee Training and Development: Typical Reasons and Benefits.

20. Obisi C (1996) Personnel Management. Freeman Publications, Ibadan.

21. Campbell J (1971) Personnel Training and Development: Annual Review of Psychology.

22. Federal Republic of Nigeria (1976) Guidelines for Local Government Reforms Government Printer, Kaduna.

23. Armstrong M (1995) A Handbook on Personnel Management Practices. Kogan Page Ltd, London.

24. Ejiogu A (2000) Human Resource Management towards Greater Productivity Generation Press Ltd, Lagos.

25. Green H (1975) Adminstrative Training: Some Implication of Udoji Commission Report. Quarterly Journal of Administration 10: 55-68.

26. Alo O (1999) Human Resource Management in Nigeria. Business Science Books, Lagos.

27. Koontz H, O’Donnel C, Weihrich H (1980) Management. McGraw Hill Publishing Company, Japan.

28. Atiomo A (2000) Human Resource Management. Malthouse Management Science Book, Lagos.

29. Obisi C (2001) Employee Development, Issues and Dimension. Unical Journa of Public Administration for September 1: 32-41.

30. Beach D (1980) Personnel Management of People at Work. Macmillan Publishing Company.

31. Robbins S (1978) Personnel: The management of Human Resources. PrenticeHall Inc, New Jersey.

32. Clothier, Spriegel (1977) Personnel Management: Principles, Practices and Point of View. Tata McGraw-Hill Publishing Company Ltd. New Delhi.

33. The Presidency (1995) Revised Guidelines for Training in the Federal Civi Service. The Presidency, Lagos.

34. Cumminng C (1968) The Theory and Practice of Personnel management. Heineman, London.

35. Burak Elmar, Smith R (1977) Personnel Management: A Human Resouce System Approach. West Publishing Company, New York. 